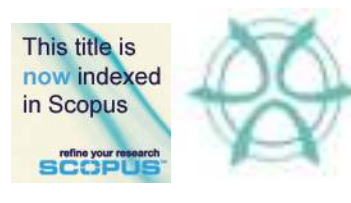

PLANNING MALAYSIA:

Journal of the Malaysian Institute of Planners

SPECIAL ISSUE IV (2016), Page 315 - 328

\title{
ANALYSIS OF SHRINES PROPERTIES USING REMOTE SENSING APPROACH: CASE STUDY OF LEMBAH BUJANG
}

\author{
Shairatul Akma Roslan ${ }^{1}$, Norzailawati Mohd Noor ${ }^{2}$, Alias Abdullah ${ }^{3} \&$ Zuraini \\ Md Ali ${ }^{4}$ \\ ${ }^{1,2,3}$ INTERNATIONAL ISLAMIC UNIVERSITY MALAYSIA \\ ${ }^{4}$ UNIVERSITI MALAYA
}

\begin{abstract}
The heritage of Lembah Bujang, Kedah is important as a starting point to understand the origins and history of civilization in Malaysia. This research is to analyze the spectral reflectance of shrines properties in an identified area by using remote sensing techniques in conserving this cultural heritage site. The remote sensing device (Spectroradiometer) was used to measure the spectral reflectance of the source of shrines in the study area. This tool was applied for reflectance's test over properties such as ancient brick, granite, literates and iron in a different two study areas consist of Lembah Bujang and Kompleks Sungai Batu. Remote sensing test properties demonstrate that discrimination of properties types of each civilization is possible through reflection measurement, but that discrimination is complicated by surface conditions, such as weathering and lichen growth. Comparison between clays, granite and iron show that clays to be more reflective than granite and iron. This result will help more in our further study on detecting these properties direct through remote sensing imagery and will be helpful in developing new indexes and selection of threshold value on shrines material in the case study of Lembah Bujang.
\end{abstract}

Keyword: Shrines, Lembah Bujang, Remote Sensing, Spectroradiometers, Land Use Planning

\section{INTRODUCTION}

Lembah Bujang is located in Sungai Petani, Kedah (northern Malaysia), and specifically in Merbok district of Kuala Muda. It became a starting point of the civilization of the Kedah Tua Kingdom and a strategic area for a trade and industry (Jacq-Hergoualc'h, 1992, Bellwood 1997). In the fourteenth century, the Merbok Estuary was an important port and trading center for traders from China, India and the Middle East (Khoo, 1996). It has been believed that over 50 shrines and hundreds of the relics are displayed in Lembah Bujang (Erna et.al, 2013). Unfortunately, the actual boundary of shrine area is not clearly determined, thus, only Lembah Bujang and Kompleks Sungai Batu has been gazette in Kuala Muda Local Plan 2020 as a heritage zone.

Spectral reflectance is one of the methods to identify the indexes and selection of threshold value over the selection of shrine properties. Field measurements of surface 
Shairatul Akma Roslan, Norzailawati Mohd Noor, Alias Abdullah \& Zuraini Md Ali

Analysis of Shrines Properties using Remote Sensing Approach: Case Study of Lembah Bujang

reflectance are widely used in the number of remote sensing analytical approaches such as vegetation canopy reflectance modeling (Rosema et al., 1992). The feasibility of using airborne multispectral remote sensing reflection measurements for discrimination of rock types has recently been investigated (Watson and Rowan, 1971). It measures the amount of energy reflected from the ground area, material or object over different wavelength (Milton, 1987). The measurement of spectral reflectance is made with these spheres by comparing the reflectance signal from the sample to the reflectance beam signal and then making the same comparison with the reflectance standard in place of the shrines sample from the area. The spectral reflectance or reflectance spectrum curve is the plot of the reflectance as a function of wavelength. The reflectance values are independent of time, location, illumination intensity, atmospheric condition, and weather. The aim of this paper is to differentiate the spectral curvatures of shrine properties according to the function of places and age of civilization. The variations of shrine properties value will be affected by the soil and mineralogical differences or particle size effects.

\section{STUDY AREA}

Lembah Bujang is located in Merbok, Kedah, between Jerai Mount (1,300 meters high) in the north and Muda River in the south of Kedah, Malaysia. Lembah Bujang holds a significant value as a physical prove of the earliest civilization in the Southeast Asia region. The specific study area is divided into two main areas consist of Lembah Bujang and Kompleks Sungai Batu as shown in Figure 1 and Figure 2.

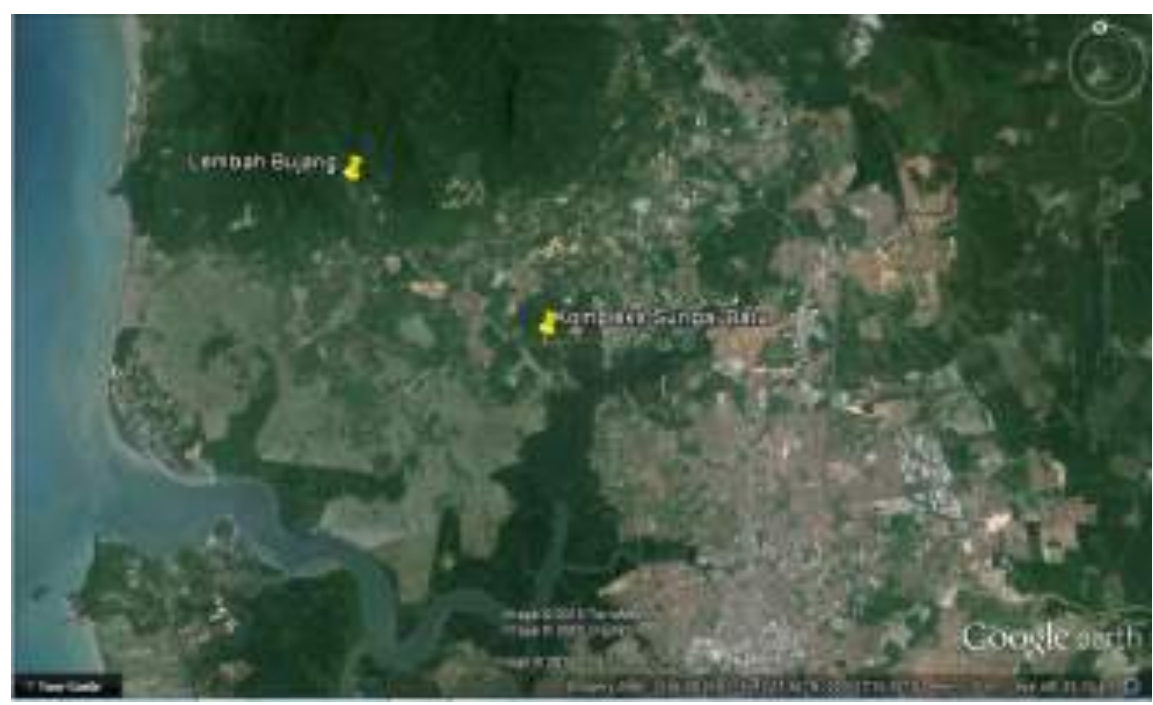

Figure 1: Site Plan of the study area (Source: Google Earth, 18 October 2015) 

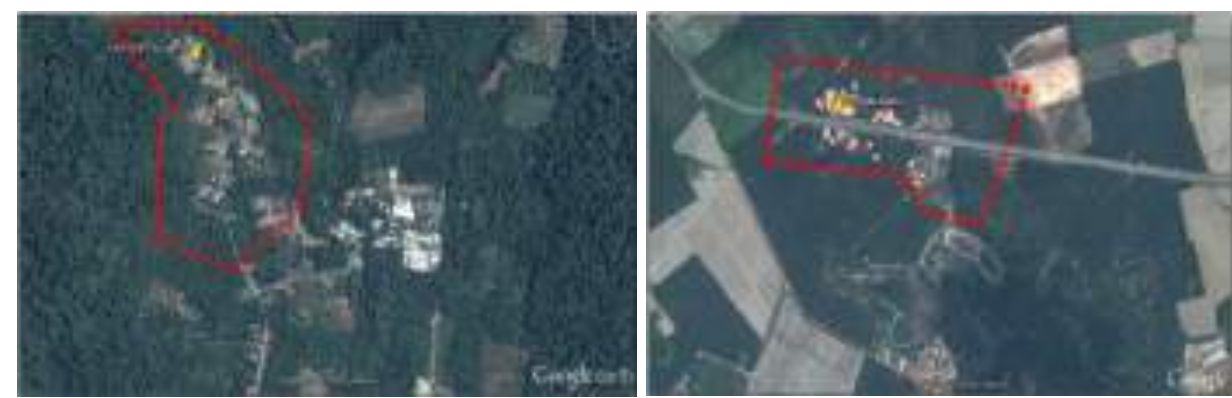

Figure 2: Location Map of Lembah Bujang (Left) and Kompleks Sungai Batu (Right)

(Source: Google Earth, 18 October 2015)

\section{METHODOLOGY OF RESEARCH}

The purpose of this study is to examine the spectral reflectance of shrines properties in the study area by using the remote sensing device; Spectroradiometer. Clays, granite, literates and iron in a different two study of Lembah Bujang and Kompleks Sungai Batu has been choosing for the reflectance's test. The shrine properties have been recorded according to the function of places and age of civilization where it was located. The specific detail of every shrine properties is shown in Table 1 . A conceptual flow diagram shown in Figure 3 will explain the methodology of this study.

Table 1: Location and the samples collection

\begin{tabular}{|c|c|c|c|}
\hline Location & $\begin{array}{c}\text { Shrines properties / } \\
\text { Sample }\end{array}$ & $\begin{array}{l}\text { Description of } \\
\text { the site }\end{array}$ & $\begin{array}{c}\text { Beginning of } \\
\text { Century }\end{array}$ \\
\hline Lembah Bujang & Granite and Literates & $\begin{array}{l}\text { Lembah Bujang } \\
\text { Museum } \\
\text { Archaeology }\end{array}$ & $\begin{array}{l}4^{\text {th }} \text { Century } \\
\text { (Coedes, 1968) }\end{array}$ \\
\hline Sungai Batu & $\begin{array}{l}\text { Ancient Clay : } \\
\text { 1) Site SB1B } \\
\text { 2) Site SB1A }\end{array}$ & $\begin{array}{l}\text {-An ancient brick } \\
\text { structure shows a } \\
\text { spiritual/ sacred } \\
\text { area } \\
\text { - Ancient } \\
\text { riverside jetty } \\
\text { which located } \\
\text { near to paleoriver } \\
\text { at Sungai Batu }\end{array}$ & $\begin{array}{l}\text { Early of } 2^{\text {nd }} \text { century } \\
\text { CE }\end{array}$ \\
\hline & $\begin{array}{l}\text { Iron: } \\
\text { 1) Site SB2A }\end{array}$ & $\begin{array}{l}\text {-Iron smelting } \\
\text { kiln }\end{array}$ & $\begin{array}{l}\text { From } 1^{\text {st }-14 \text { th }} \text { Century } \\
\text { CE }\end{array}$ \\
\hline
\end{tabular}

Source: Stephen Chia, Barbara Watson Andiya, 2011 
Shairatul Akma Roslan, Norzailawati Mohd Noor, Alias Abdullah \& Zuraini Md Ali

Analysis of Shrines Properties using Remote Sensing Approach: Case Study of Lembah Bujang

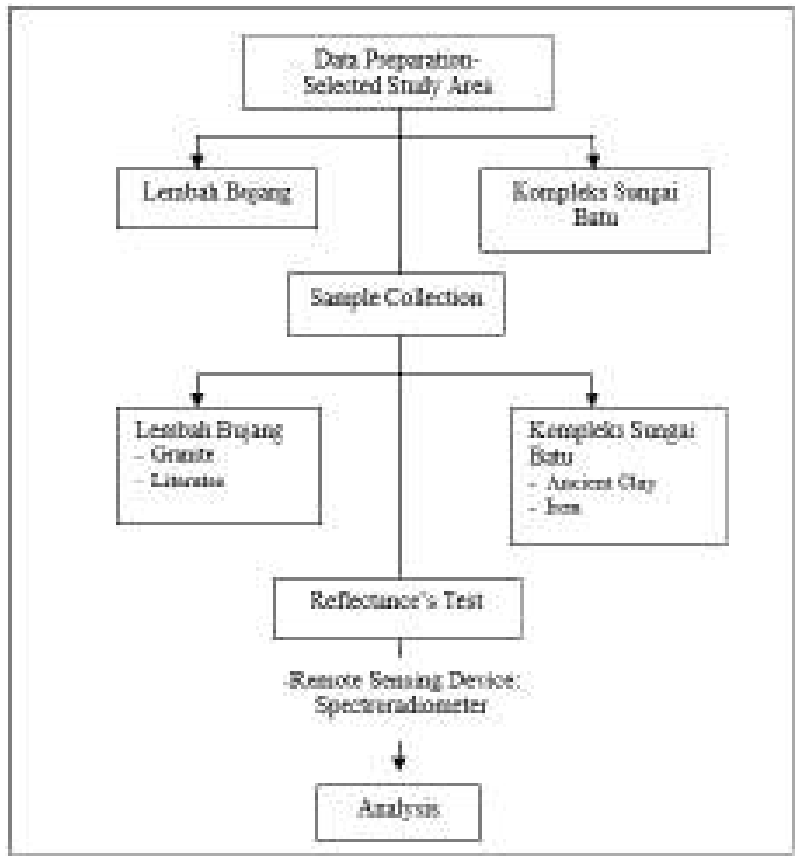

Figure 3: A conceptual flow diagram for Analysis of Shrines Properties using Remote Sensing Approach

\section{METHODS}

Field measurements were carried out in two different archaeological areas in Lembah Bujang, Kedah which Lembah Bujang and Kompleks Sungai Batu. Moreover, ground Spectroradiometer measurements were taken: a) over shrines features or materials such as ancient brick, granite and literate depend on site material in order to develop an archaeological spectral signature database and b) at iron smelting kiln area in Kompleks Sungai Batu. The Spectroradiometer instrument that was used to register the spectral signature was GER1500. Figure 4 shows an instrument that may record electromagnetic radiation from a range of $400 \mathrm{~nm}$ up to $1000 \mathrm{~nm}$.

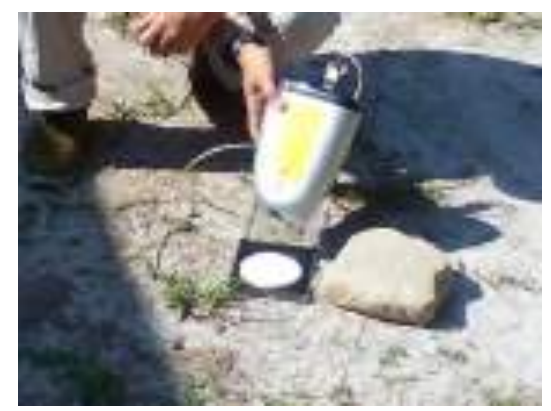

Figure 4: Reflectance's test in site $S B 1 A$ - an ancient jetty structure (ancient brick) dated early of the $2^{\text {nd }}$ century CE using Spectroradiometer 


\section{Lembah Bujang}

In Lembah Bujang, two different types of material (granite and literate) for ground Spectroradiometer measurements were taken while in each consecutive 10th measurement the calibration spectral on the panel was used in order to minimize sun changes illuminations.

\section{Kompleks Sungai Batu}

In Kompleks Sungai Batu, two different types of material (ancient clay and iron) for ground spectroradiometer measurements were taken for Spectroradiometer test. The actual reflectance measurements are usually performed under illuminating and viewing conditions recommended by $\mathrm{CIE}^{2}: 45^{\circ} / 0^{\circ}, 0^{\circ} / 45^{\circ}$, diff $/ 0^{\circ}$ and $0^{\circ} /$ diff where diff stand for diffuse.

\section{ANALYSIS AND FINDING}

\section{Reflectance of Lembah Bujang}

Most of the construction materials for the temple at Lembah Bujang site were made of clays, river rock (pebbles), mineral literate and granite as display in Figure 5. There are several famous temples had been uncovered in the Lembah Bujang, among of them are the Candi (Temple) Bukit Batu Pahat (Site 8), Candi Kampung Pangkalan Bujang (Site 19, 21 and 22), Candi Estet Sungai Batu (Site 5 and 11/3), Candi Kampung Pendiat (site 16), Candi Kampung Permatang Pasir (site 31) and Candi Kampung Bendang Dalam (site 50). All these temples became evident that the Lembah Bujang was under the Hinduism influenced at that time. However, part of the original structure has been destroyed and cannot be reconstructed from natural disasters such as floods, erosion, World War II or destroyed by local people.

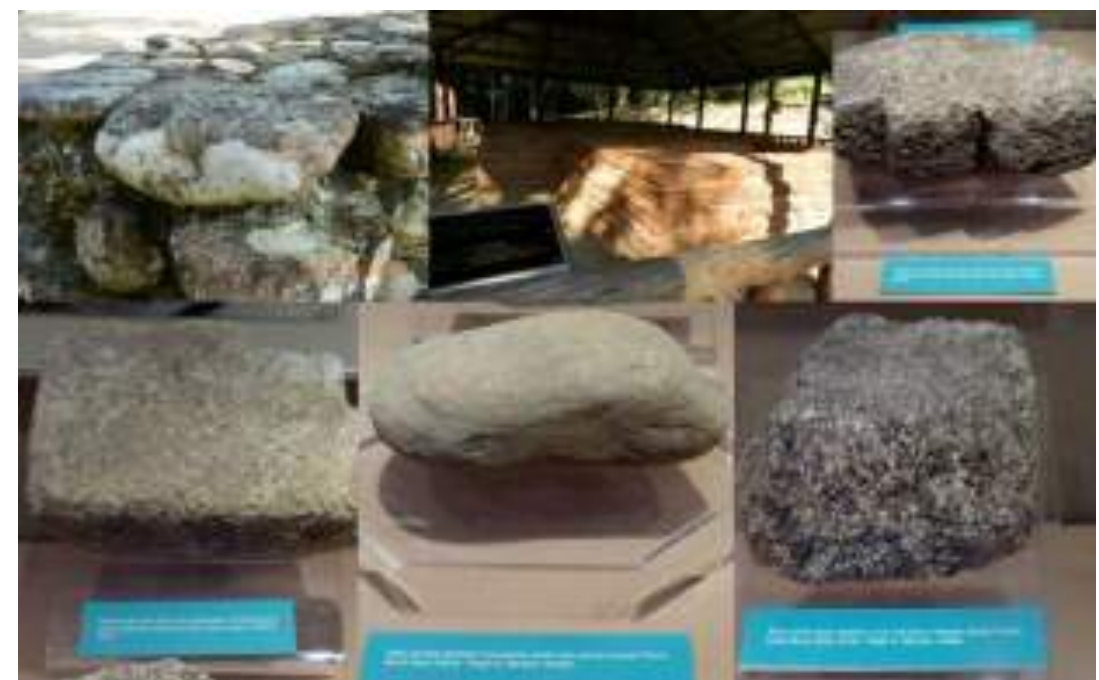

Figure 5: The material used for structure - Candi Batu Pahat and Candi Pendiat at Lembah Bujang 
Shairatul Akma Roslan, Norzailawati Mohd Noor, Alias Abdullah \& Zuraini Md Ali

Analysis of Shrines Properties using Remote Sensing Approach: Case Study of Lembah Bujang

\section{Reflectance's' Analysis of Lembah Bujang}

The spectral signature diagram is an easy way to plot target reflectance against wavelength, in a graphical form. Therefore, ground field measurements from archaeological sites may be used in order to create an "archaeological" digital spectral signature. In Lembah Bujang site, different spectral signatures of the materials were taken. The result shows in diagram 1a and 1b Figure 6 the spectra value of granite is higher than literate spectra value.

(1a)

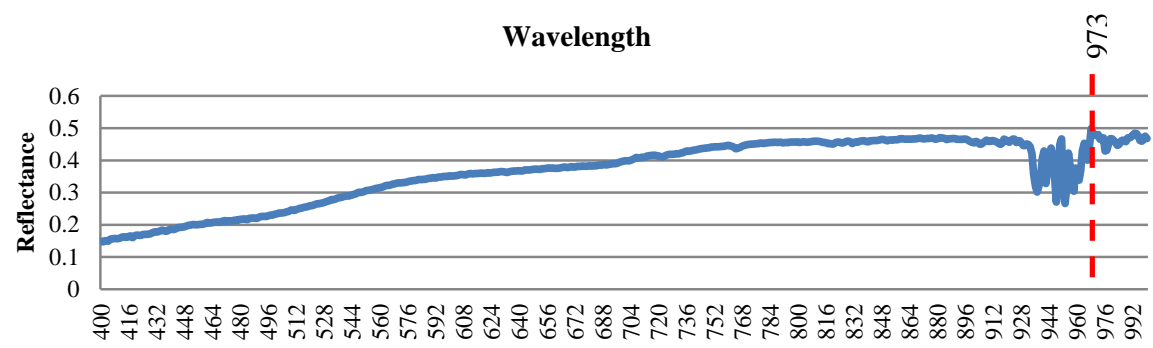

(1b)

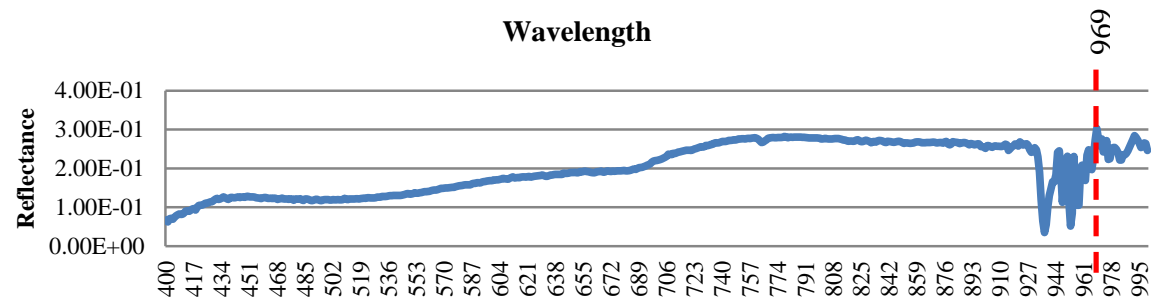

Figure 6 (1a) and (1b): Diagram shows the result of the reflectance test on granite (1a) and Literate (1b)

\section{Kompleks Sungai Batu}

The site was divided into two sides, Sungai Batu 1 - SB1 and Sungai Batu - SB2. These both site SB1 and SB2 are situated in a private oil palm estate along new MerbokSemeling road. It is situated near Sungai Batu, a tributary of Sungai Merbok. (Stephen Chia, 2011). In site SB1, based on 2009- 2010 excavation, 1) an ancient clays structure in Figure 7 shows a spiritual/ sacred area dated to the early $1^{\text {st }} 2^{\text {nd }}$ century CE (site SB1B) and 2) an ancient roofed clay platform, believed to be a jetty which located near to paleoriver at Sungai Batu, dated to early of the $2^{\text {nd }}$ century CE (site SB1A) meanwhile, in site $\mathrm{SB} 2$, they found iron smelting industry used from $1^{\text {st }}$ century CE in site SB2A and site SB2C from $8^{\text {th }}-11^{\text {th }}$ CE. Besides, they also found an ancient jetty which continuously from site SB1A in site SB2E along paleo-river at Kompleks Sungai Batu. 

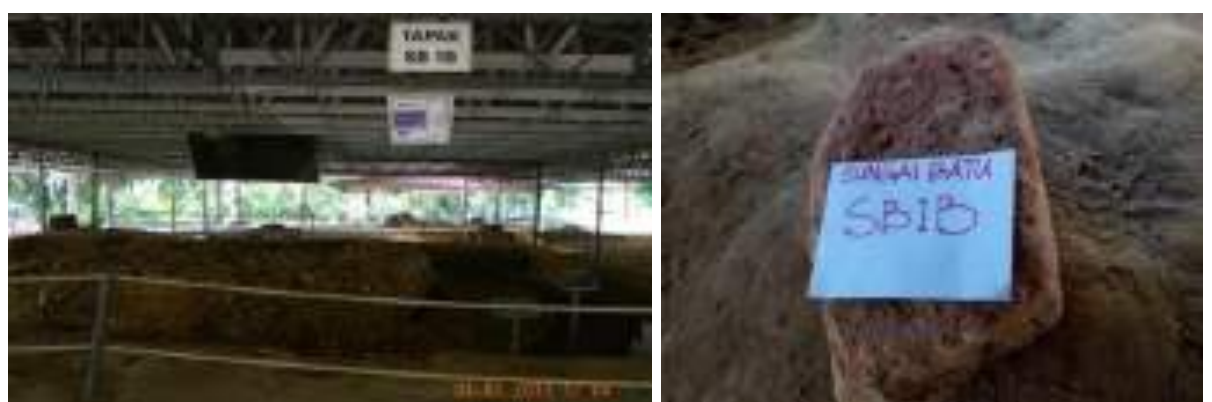

Figure 7: Monument at site SB1B- A circular clays floor with a square clays structure on top of it and small round clays structure on top of square clays structure.

\section{Sungai Batu- SB1B and SB2A}

In site SB1B for instances there a monument such a circular clay floor with a small square clay structure on top of. The reflectance's test is on ancient brick with two different situations- open area and under roof. In Sungai Batu site, same spectral signatures of the materials (ancient clay) were taken but in different condition. On the other hand, in site SB1A, there is believed to be an ancient jetty based on the location of the structure which near to the river bank of the ancient Sungai Batu which established early of $2^{\text {nd }}$ century CE. The reflectance's test is on ancient brick as shows in Figure 9 with two different situations- open area and under roof.

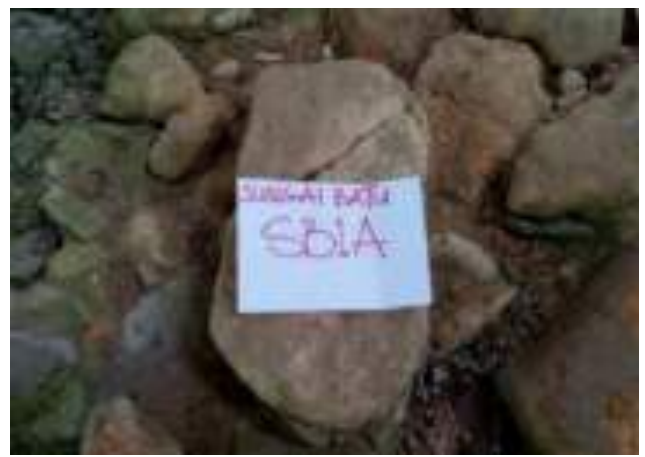

Figure 9: Sample (brick) that used for reflectance's test in site $S B 1 A$

\section{Reflectance's' Analysis of Sungai Batu-SB1B}

Figure $8(2 \mathrm{a})$ shows that the result of spectra was taken in an open area exposed to the lighting. However (2b) shows the result of spectra was taken under the roof in site SB1B. The result shows the spectra value in an open area is higher than spectra value in under roof. 
Shairatul Akma Roslan, Norzailawati Mohd Noor, Alias Abdullah \& Zuraini Md Ali

Analysis of Shrines Properties using Remote Sensing Approach: Case Study of Lembah Bujang

(2a)
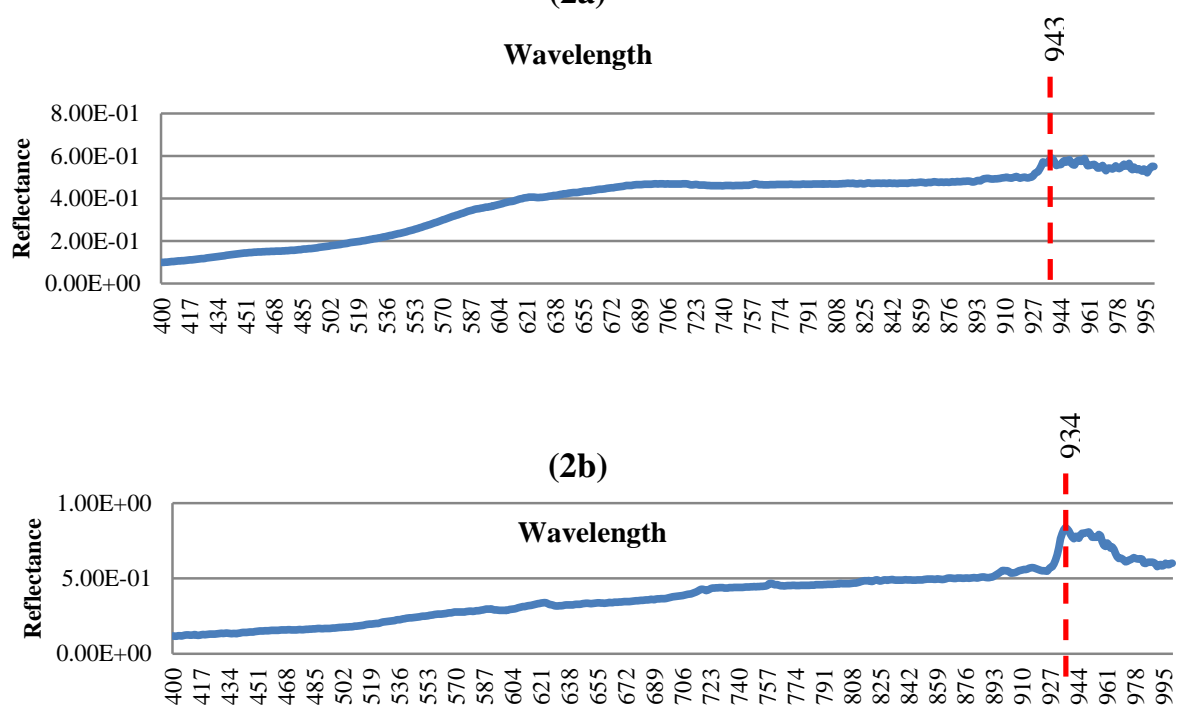

Figure 8 (2a) and (2b): Typical spectral reflectance characteristic for ancient brick in site $S B 1 B$; an ancient clay structure of a spiritual/sacred area dated to the early $2^{\text {nd }}$ century CE.

\section{Reflectance's' Analysis of Sungai Batu- SB1A}

Figure 10(3a) shows that the result of spectra was taken in the open area which exposed by the lighting, however (3b) shows the result of spectra was taken under the roof in site $\mathrm{SB} 1 \mathrm{~A}$. The result shows the spectra value in an open area is higher than spectra value in under roof. 
(3a)

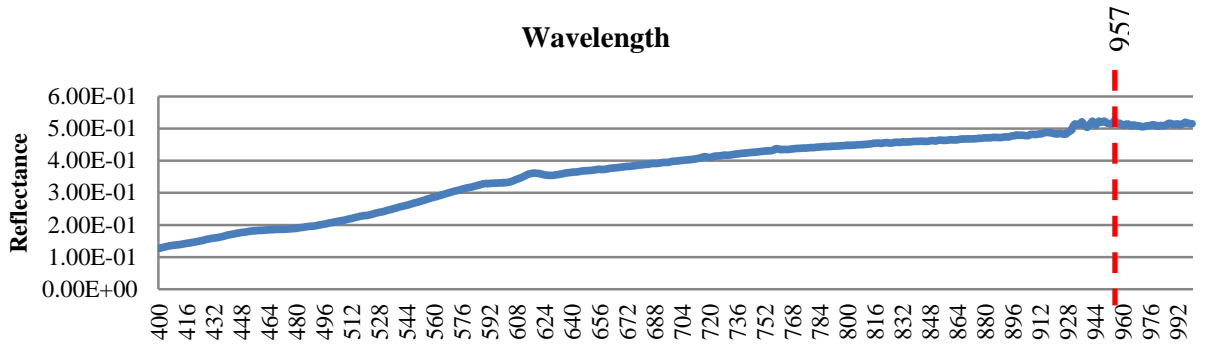

(3b)

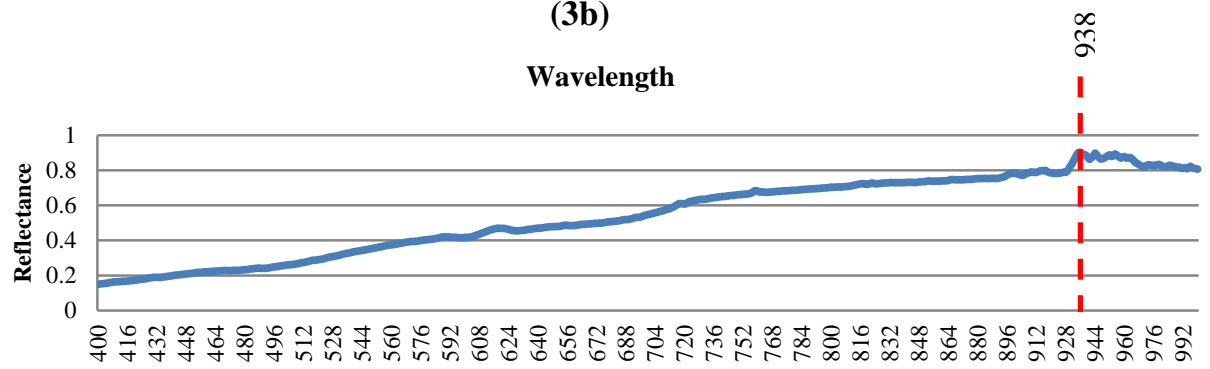

Figure 10 (3a) and (3b): Typical spectral reflectance characteristic for ancient brick in site $S B I A$ - an ancient jetty that believed established early of the $2^{\text {nd }}$ century CE

\section{Sungai Batu- SB2A}

In site SB2A, the reflectance's test is of clay and iron (iron smelting kiln) as shown in Figure 11. In this site, CGAR was found an iron smelting industry structure used from $1^{\text {st }}$ century $\mathrm{CE}$. Besides, thousands of pieces of iron ore and iron slag, there are also a large number of clay pipes which used to blow air into the iron smelting furnaces. The latest findings from PPGA is ancient jetty in site SB2 namely SB2E which continuously from the ancient jetty at SB1A.
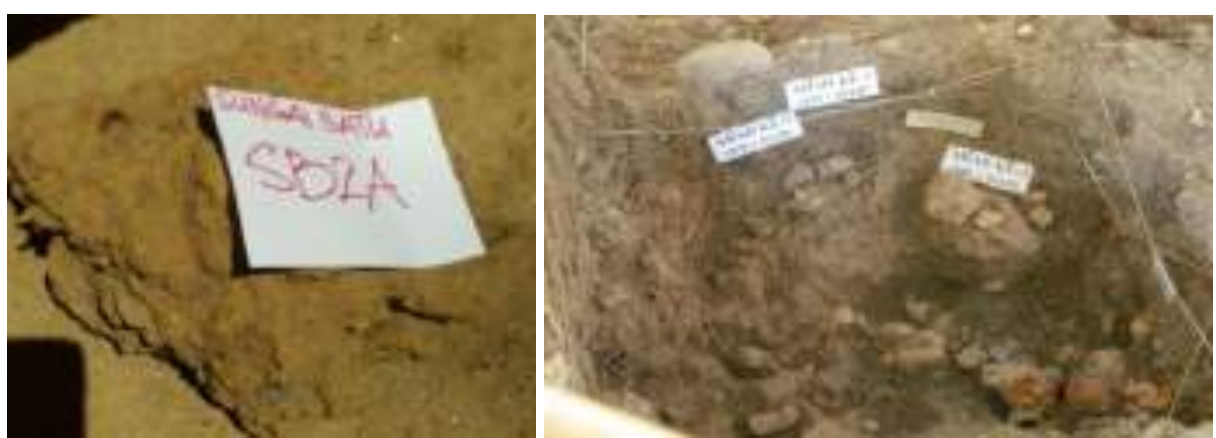

Figure 11: Sample; Iron that used for reflectance's test in site SB2A 
Shairatul Akma Roslan, Norzailawati Mohd Noor, Alias Abdullah \& Zuraini Md Ali

Analysis of Shrines Properties using Remote Sensing Approach: Case Study of Lembah Bujang

\section{Reflectance's' Analysis of Sungai Batu-SB2A}

In site SB2A different spectral signatures of the materials were taken which ancient clay and iron in the same area; iron smelting kiln site from 1 Century CE. The result shows in diagram $4 \mathrm{a}$ and $4 \mathrm{~b}$ Figure12, the spectra value of iron is lower than spectra value of ancient brick in the same area.

(4a)

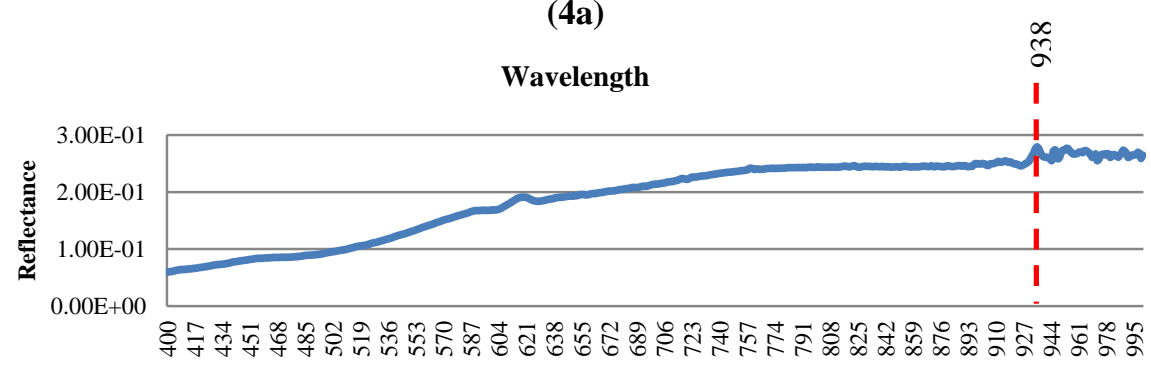

(4b)

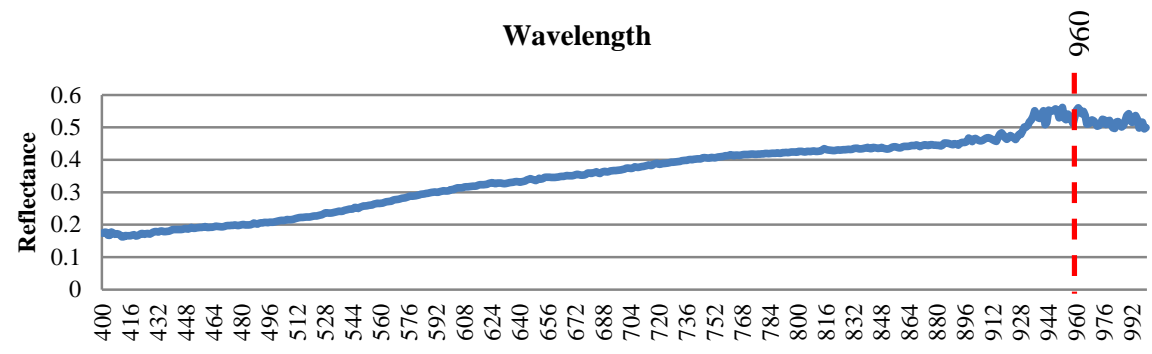

Figure 12 (4a) and (4b): Typical spectral reflectance characteristic for iron in site $S B 2 A$ - iron smelting kiln used from $1^{\text {st }}$ century CE

Reflectance's' Analysis of Sungai Batu-SB2E

In site SB2E as display in Figure 13, the result of reflectance's test over sample ancient brick as shown in Figure 14.
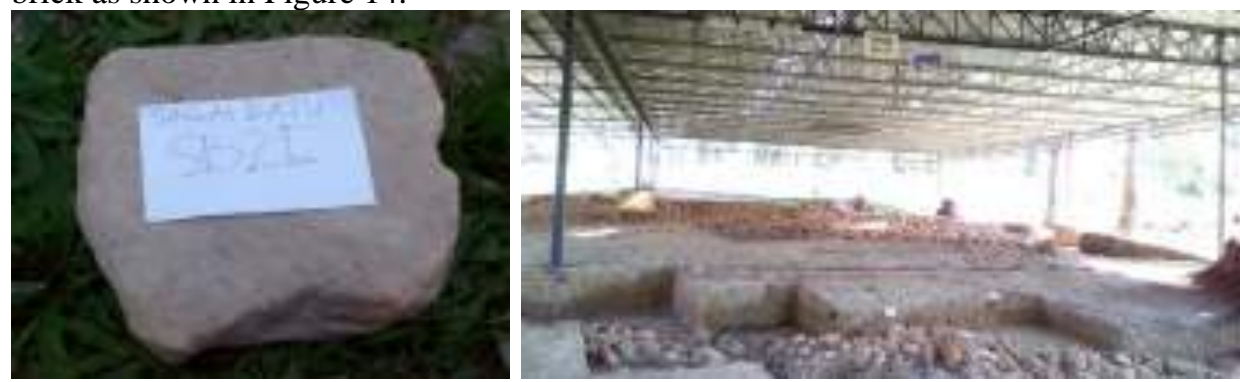

Figure 13: the ancient clay that used for reflectance's test in site $S B 2 E$ - ancient jetty continuously from ancient jetty at site SB1A 


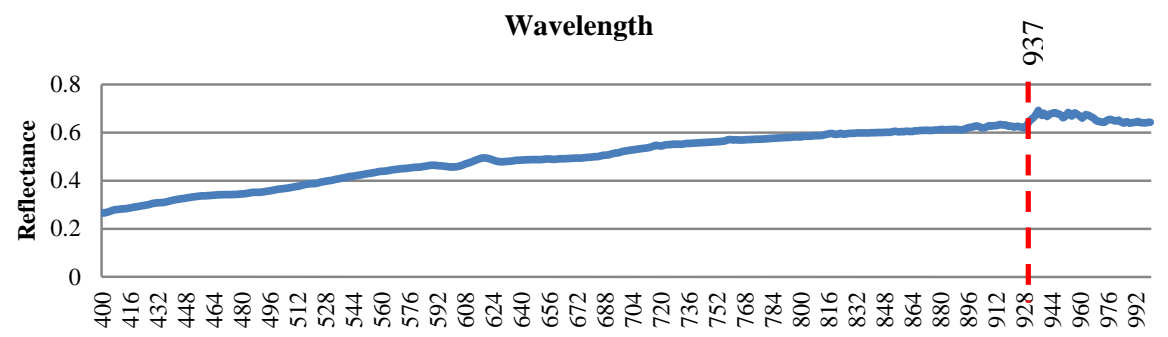

Figure 14: Typical spectral reflectance characteristic for ancient brick in site $S B 2 E$

\section{RESULT}

Figure 15 shows the comparison of the spectra value after average all the wavelength index between iron, clay, and granite in two different locations of Lembah Bujang and Kompleks Sungai Batu. The result shows that ancient brick to be more reflective than granite and iron.

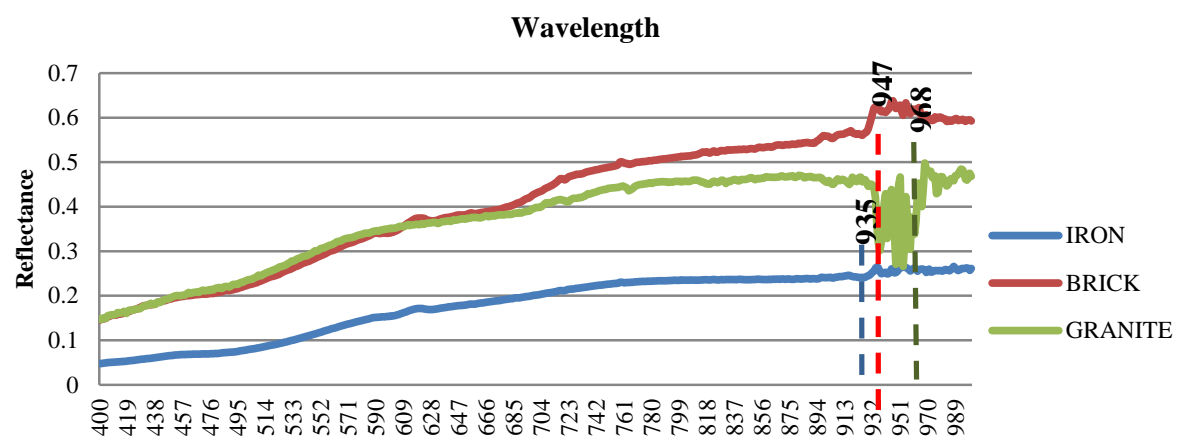

Figure 15: Comparison Reflectance Results between Iron, Ancient Brick and Granite

\section{CONCLUSION}

The study found that the reading of wavelength in all samples in two different location are $900 \mathrm{~nm}$ and above. Here we can assume that all the shrines properties magnitude length is situated in 700-1400 nm-wavelength of near-infrared radiation. Secondly, there are possible reading errors may arise due to the inability of the measuring the samples to properly compare to the reflectance curved and the flat surface either due to the difference in the relative area or by the sample properties laid by the ground and not be clean before the test or due to inconsistent lighting such as vegetations or weather condition when the sample is taken.

Moreover, it was proved that Spectroradiometer measurements can be used as an alternative approach in order to identify archaeological properties since they can provide accurate spectral signatures for a wide spectral region. Anomalies of the shrines properties spectral signatures, for instance, can be recorded in detail and contribute to the 
Shairatul Akma Roslan, Norzailawati Mohd Noor, Alias Abdullah \& Zuraini Md Ali

Analysis of Shrines Properties using Remote Sensing Approach: Case Study of Lembah Bujang

construction of a predictive archaeological model in the future. Furthermore, this study is efficient for any potential researcher to combine this spectral signature and satellite imagery in order to detect archaeological relics in the area because it highlights the high correlation of spectral response of archaeological material and local geological formations in the area.

\section{ACKNOWLEDGEMENT}

The authors greatly acknowledge the Universiti Malaya for research grant on Program Rakan Penyelidikan; Research Grant titled Remote Sensing and GIS in Preservation of Historical Site in Lembah Bujang through Efficient Land Use Planning (CG016-2014) with International Islamic University of Malaysia, Malaysia Remote Sensing Agency and Town and Urban Planning Department, Centre for Global Archaeological Research (CGAR), Universiti Sains Malaysia, Department of National Heritage and Universiti Teknologi Malaysia for providing invaluable respective data used in this study. Authors sincerely thank all referees for their suggestions to improve the manuscript.

\section{REFERENCES}

Milton, E. J.(1987)'Review Article Principles Of Field Spectroscopy', International Journal Of Remote Sensing,8:12,1807 - 1827

Peddle, D.R., Johnson, R.L., (2000). Spectral Mixture Analysis Of Airborne Remote Sensing Imagery For Improved Prediction Of Leaf Area Index In Mountainous Terrain, Kananaskis Alberta. Canadian Journal Of Remote Sensing 26 (3), 176187.

Simone Kotthaus, Thomas E.L. Smith, Martin J. Wooster, C.S.B. Grimmond. (2014). Derivation Of An Urban Materials Spectral Library Through Emittance And Reflectance Spectroscopy. ISPRS Journal Of Photogrammetry And Remote Sensing , 1-19.

Stephen Chia, B. W. (2011). Bujang Valley And Early Civilisation In Southeast Asia. Malaysia: Department Of National Heritage, Malaysia

Deering, D.W., (1989). Field Measurements of Bi-Directional Reflectance. In: Asrar, G. (Ed.), Theory and Applications Of Optical Remote Sensing. Wiley, New York, Pp. 14-65.

Derek R.Peddle, H.Peter White, Raymond J.Soffer, John R.Miller, Ellsworth F.Ledrew. (2001). Reflectance Processing Of Remote Sensing Spectroradiometer Data. Computer And Geosciences , 1-11.

Escalante, D. B. (June, 2012). Remote Sensing - Applications In Archeology. Remote Sensing - Applications In Archeology, 1-29.

G. Schaepman-Strub, T. Painter, S. Huber, S. Dangel , M. E. Schaepman , J. Martonchik , F. Berendse (2006) (N.D.). About The Importance Of The Definition Of Reflectance Quantities -Results Of Case Studies. About The Importance Of The Definition Of Reflectance Quantities -Results Of Case Studies , 1-6

Jackson, R.D., Clarke, T.R., Moran, M.S.,(1992). Bidirectional Calibration Results For 11 Spectral On And 16 Based on Reference Reflectance Panels. Remote Sensing Of Environment 40, 2310-2319. 
Khoo TT (1996) Geomorphological evolution of the Merbok Estuary area and its impact on the early state of Kedah, northwest peninsular Malaysia. J Southeast Asian Earth Sci 13:347-371.

Lee, C. P. (2006). The Cambrian of Malaysia. Palaeoworld, 1-14.

Martonchik, J.V.,Bruegge, C. J., \& Strahler, A. (2000). A Review Of Reflectance Nomenclature Used In Remote Sensing. Remote Sensing Reviews, 19, 9-20.

Misura, K.M., Barber, D.G., Ledrew, E.F., (1993) Seasonal Sea Ice Monitoring and Modeling Site: Simms 1993 Data Report. Waterloo Laboratory for Earth Observations, De- Partment Of Geography, University Of Waterloo, Waterloo, On, Canada. Ists-Eol-Sims Report No. Tr93-007, 377pp.

Mokhtar Saidin, J. A. (2010). Issues And Problem Of Previous Studies In The Bujang Valley And The Discovery Of Sungai Batu. Bujang Valley And Early Civilisation In Southeast Asia , 1-26.

Poh-Eng Lim*, Chow-Kum Leer And Zubir Dini". (1995). Accumulation Of Heavy Metals By Cultured Oysters From Merbok Estuary, Malaysia. 1-4.

Ray D. Jackson ,M.Susan Moran, Philip N.Slater And Stuart F.Biggar . (1987). Field Calibration Of Reference Refelctance Panel. Remote Sensing Of Environment, 114.

Robinson, B. F., And Biehl, L. L. (1979), Calibration Procedures For Measurement Of Reflectance Factor In Remote Sensing Field Research, J. Soc.Photo-Opt. Instr. Eng. 196: 16-26

Rosema, A., Verhoef, W., Noorbergen, H., \& Borgesius, J. J. (1992). A New Forest Light Interaction Model In Support Of Forest Monitoring. Remote Sensing Of Environment, 42, 23- 41

Teillet, P.M., (1995). The Role Of Surface Observations In Support Of Remote Sensing. In: Ledrew, E.F., Strome, M., Hegyi, F. (Eds.), The Canadian Remote Sensing Contribution To Understanding Global Change. Department Of Geography Publication Series, No. 38, University Of Waterloo, Waterloo, On, Canada, Pp. 333-352

Toru Toru Tamura, Fumitoshi Murakami, Futoshi Nanayama,Kazuaki Watanabe, Yoshiki Saito. (2007). Ground-penetrating radar profiles of Holocene raisedbeach deposits in the Kujukuri strand plain, Pacific coast of eastern Japan. Marine Geology 248 (2008) 11-27, 1-17.

Watson, R. D. (1972). Spectral Reflectance And Photometric Properties Of Selected Rocks. Remote Sensing Of Environment 2, 95-100 (1972) , 1-6

Johnson, R.L., Peddle, D.R., Hall, R.J., Mah, S., (1999). Spectral Mixture Analysis Of Montane Forest Biophysical Parameters: A Comparison Of End members From Airborne Imagery And A Field Spectroradiometer. Proceedings Of The Fourth International Airborne Remote Sensing Conference And $21{ }^{\text {st }}$ Canadian Symposium On Remote Sensing, Ottawa, Canada, Vol. Ii, Pp. 107-114.

Peddle, D.R., Smith, A.M., Ivie, C., Bullock, M., Russell, S., (1999a). Spectral Mixture Analysis Of Agricultural Crops Under Different Irrigation Regimes: Scene Fraction Validation In Potato Plots. Proceedings of the Fourth International Airborne Remote Sensing Conference and 21st Canadian Symposium on Remote Sensing, Vol. Ii, Ottawa, Canada, Pp. 275-282. 
Shairatul Akma Roslan, Norzailawati Mohd Noor, Alias Abdullah \& Zuraini Md Ali

Analysis of Shrines Properties using Remote Sensing Approach: Case Study of Lembah Bujang

Peddle, D.R., Ledrew, E.F., Holden, H.M., (1995). Spectral Mixture Analysis Of Coral Reef Abundance From Satellite Imagery And In Situ Ocean Spectra, Savusavu Bay, Fiji. Third Thematic Conference On Remote Sensing Of Marine And Coastal Environments, Vol. Ii, Seattle, Wa, Usa, Pp.563-575

R. D. Watson, And L. C. Rowan, In 7th Internat. Symposium On Remote Sensing Of Environment, Ann Arbor, Mich., May 17-21,(1971), Proceedings (In Press).

Kedah, P. P. (N.D.). Sejarah Awal Lembah Bujang. Retrieved February 11, 2015, From Memori:

Http://MemoriKedah.Com/Page_Pengenalan.Php?P=2\&Idstopic=47\&Idskandun gan $=190 \&$ Mtopic $=5$

Nicodemus,F.E.,EtAl.(1977).Geometrical Considerations and Nomenclature for Reflectance. Washington, Dc: National Bureau of Standards, Us Department Of Commerce. Url: Http://Physics.Nist.Gov/Divisions/Div844/ Facilities/Specphoto/Pdf/Geoconsid.Pdf 